\title{
Erratum zu: Einführung
}

Matthias Bormuth

\section{Erratum zu: \\ Kapitel „Einführung“ in: D. Lamping und G. Tihanov (Hrsg.), Vergleichende Weltliteraturen / Comparative World Literatures, https://doi.org/10.1007/978-3-476-04925-4_27}

Auf S. 406-408 wurde der Text unter Ziffer V. ausgetauscht und durch eine revidierte Fassung ersetzt. 